\title{
Omnibus Law Sebagai Solusi Hiper-Regulasi Menuju Sonkronisasi Peraturan Per-Undang-Undangan di Indonesia
}

\author{
Muhamad Azhar \\ Fakultas Hukum Universitas Diponegoro, \\ Correspondent Author: azhar@live.undip.ac.id
}

\begin{abstract}
This study aims to determine the application of the omnibus law concept as a solution to hyperregulation towards synchronization and harmonization of laws and regulations in Indonesia. The research method used is legal research using a comparative approach and a comparative approach. Overall data analyzed using synthesis analysis. The results of the study show that the application of the concept of the omnibus law as a solution to the regulation in Indonesia. Hype-regulation in Indonesia occurs at every level of laws and regulations. The potential for overlapping legal regulations including 7621 ministerial regulations, 765 Presidential Regulations, 452 government regulations, and around 30,000 regional regulations. The hyper-regulation puts a burden on the synchronization and harmonization of laws and regulations in Indonesia. There is not even one institution that can monitor and evaluate the existence of the hyper-regulation. The synchronization and alignment are carried out within the framework of the four pillars as the basis of the Indonesian Republic. Thus, it is necessary to implement a study on the application of Omnibu law as a solution to the hyper-regulation of legislation in Indonesia.
\end{abstract}

Keywords: Omnibus Law, Hyperregulation, Singronization, Harmonization, Regulation.

\begin{abstract}
Abstrak
Penelitian ini bertujuan untuk mengetahui penerapan konsep omnibus law sebagai solusi hiperregulasi menuju sonkronisasi dan harmonisasi peraturan perundang undangan di Indonesia. Metode penelitian yang digunakan adalah penelitian hukum yang menggunakan pendekatan perbadingan, dan pendekatan perbandingan. Keseluruhan data dianalisis mengguanakan analisis sitesis. Hasil penelitian menujukan bahwa penerapan konsep omnibus law sebagai solusi hiperregulasi regulasi di Indonesia. Hiperegulasi di indonesia terjadi pada setiap tingkatan peraturan perundang undangan. Potensi tumpang tindih peraturan perundang undagan diantarannya terdapat 7621 peraturan menteri, 765 peraturan presiden, 452 peraturan pemerintah dan sekitar 30.000 peratruan daerah. Hiperregulasi tersebut memberikan beban dalam melakukan sonkronisasi dan harmonisasi peraturan perundang undangan di Indonesia. Bahkan tidak ada satupun lembaga yang dapat melakukan monitoring dan evaluasi terhadap adanya hiperegulasi tersebut. Sonkronisasi dan Harmonisasi dilakukan dalam kerangka empat pilar sebagai dasar negara Rebublik Indonesia. Dengan demikian, perlu dilakukan diterapkannya kajian penerapan omnibu law sebagai solusi atas hiperregulasi perundang undangan di Indonesia.
\end{abstract}

Kata Kunci: Omnibus Law, Hiperregulasi, Singronisasi, Harmonisasi, Peraturan. 


\section{A. Pendahuluan}

Presiden Jokowi menyatakan cita-cita Indonesia Maju 2045 dalam pidato pelantikan di hadapan Sidang Majelis Permusyawaratan Rakyat (MPR) tanggal 20 Oktober 2019 dengan tiga indikator, yaitu: Pertama, pendapatan per kapita mencapai Rp320 (tiga ratus dua puluh) juta per tahun; Kedua, Produk Domestik Bruto (PDB) nominal mencapai USD 7 (Tujuh) Triliun atau setara dengan Rp98.000,- (Sembilan Puluh Delapan Ribu) Triliun-dengan nilai tukar Rp14.000,- (Empat Belas Ribu) per USD; dan Ketiga, tingkat kemiskinan mendekati nol. Mengawali langkah mewujudkan cita-cita 25 (dua puluh lima) tahun mendatang tersebut, Presiden menyebut lima pilar pembangunan, salah satunya pemangkasan regulasi dan penyiapan Omnibus Law Cipta Kerja.

Dalam melakukan penataan regulasi, teknik legislasi baru yakni teknik Omnibus Law pun diterapkan. Dengan menggunakan teknik Omnibus Law, persoalan dalam berbagai Undang-Undang tersebut dapat diselesaikan tanpa harus merevisi berbagai Undang-Undang yang substansinya terkait dengan perizinan, melainkan cukup dengan membuat 1 (satu) Undang-Undang baru yang mengamandemen pasal dalam beberapa Undang-Undang. Omnibus Law merupakan metode untuk membuat sebuah regulasi atau Undang-Undang yang terdiri atas banyak subyek atau materi pokok untuk tujuan tertentu guna menyimpangi suatu norma peraturan. ${ }^{1}$ Omnibus berbeda dengan rancangan peraturan kebanyakan dalam hal jumlah materi muatan yang dicakup, banyaknya pasal yang diatur (ukuran), dan terakhir dari sisi kompleksitas. Dalam sebuah Undang Undang Omnibus mencakup hampir semua substansi materi yang berhubungan.

Undang-Undang Omnibus mencerminkan sebuah integrasi, kodifikasi peraturan yang tujuan akhirnya adalah untuk mengefektifkan penerapan peraturan tersebut. Teknik legislasi omnibus law dari segi teoritis maupun praktis masih belum terlalu dikenal di Indonesia. Omnibus Law sendiri merupakan suatu metode untuk menghasilkan UndangUndang yang berkualitas, bukan bentuk produk hukum. Berbagai teknik/metode pembentukan peraturan perundang-undangan serupa yang telah cukup populer di Indonesia contohnya adalah Regulatory Impact Assessment (RIA) dan Rule, Opportunity, Capacity,

\footnotetext{
${ }^{1}$ Dyah Wijaningsih, Islamiyati Muhyidin, Ro'fah Setyowati. Access To Justice Nasabah Perbankan Syariah Pasca Putusan Mahkamah Konstitusi Nomor 93/PUU-X/2012. Masalah-Masalah Hukum, [S.1.], v. 43, n. 3, p. 411-419, july 2014. ISSN 2527-4716. Available at: . Date accessed: 08 dec. 2019. doi: http://dx.doi.org/10.14710/mmh.43.3.2014.411-419
} 
Communication, Interest, Process, Ideology (ROCCIPI). Merupakan suatu hal yang lazim dalam pembentukan Undang-Undang ketika terdapat norma dalam peraturan perundangundangan yang dihasilkan melalui teknik legislasi yang menghapus atau mengubah 1 (satu) norma dan mengaturnya kembali dalam undang-undang yang dibentuk. Oleh karena demikian, pada saat ini pemerintah telah menyiapkan Omnibus Law RUU Cipta Kerja. Omnibus Law RUU Cipta Kerja telah mendapat kritik, saran dan masukan dari berbai pihak dan berbagai perguruan tinggi. Semakin tinggi partisipasi publik dalam suatau rancangan peraturan perundang undangan maka semakin baik pula proses perancangan suatau aturan tersebut, termasuk RUU Cipta Kerja yang sangat gencar didiskusikan oleh berbagaia pihak pada saat ini.

Tulisan ini ingin menguraikan bagaimana masa depan Omnibus Law RUU Cipta Kerja. Pembaharuan terhadap peraturan perundang-undangan dalam rangka pembangunan hukum sangat diperlukan. Tanpa pembaharuan dan pembangunan hukum yang sesuai dengan kebutuhan masyarakat, ketimpangan bahkan hambatan bagi pembangunan nasional akan timbul. Perubahan besar-besaran regulasi ketenagakerjaan melalui Omnibus Law adalah upaya transformatif untuk memenuhi cita-cita Indonesia Maju 2045 dengan memanfaatkan bonus demografi, karena 25 (dua puluh lima) tahun bukanlah masa yang panjang untuk pembangunan ekonomi. Omnibus law hadir diharapakan menjadi kunci penyelesaian tumpang tindih peraturan perundang undangan dan carut marut regulasi di Indonesia. Pada akhir dari keberadaan omnibul law diharapkan menjadi obat mujarab bagi singronisasi dan harmonisasi peratruan perundang undangan di Indonesia.

Pro dan kontra keberadaan Omnibus law yang didorong oelh pemerintah akan selalu pasti ada. Hal tersebut harus dilihat sebagai dinamika dalam pembangunan hukum. Tidak dibenarkan melakukan justifikasi yang terlalu dini teradah langkah pemerintah tersebut. Pada artikel ini ada beberapa peramasalahan yeang mengemuka diantaranya adalah Pertama: bagaimana dasar pertimbangan atau perspektif filosofis dari keberadaan Omnibus Law disusun dan disiapkan oleh pemerintah. ${ }^{2}$

\footnotetext{
${ }^{2}$ Busroh, Firman Freaddy. Konseptualisasi Omnibus Law Dalam Menyelesaikan Permasalahan Regulasi Pertanahan. Arena Hukum, [S.1.], v. 10, n. 2, p. 227-250, aug. 2017. ISSN 2527-4406. Available at: . Date accessed: 08 dec. 2019. doi: http://dx.doi.org/10.21776/ub.arenahukum.2017.01002.4
} 
Aspek filosofis akan diuraikan dalam konteks "normative mode legal pragmatism", mendorong realitas hukum sebagai alat untuk mengabdi ke tujuan social. ${ }^{3}$ Omnibus Law apakah benar lebih mementingkan Legal pragmatism dan economic persepective dibandingkan perspektiflainnya. Dalam artian bahwa apakah benar Omnibus Law tidak memiliki prospek sama sekali untuk menjadi solusi bagi pengbangunan ekonomi nasional dan sekaligus pembangunan hukum. kedua; menjelaskan strategis reformasi regulasi agar penataan dilakukan secara sekaligus terhadap banyak peraturan perundang undangan yang ada dengan tujuan, a). Menghilangkan tumpeng tindi antar Peratruan Per-Undang-undangan. b). Efisiensi proses perubahan / pencabutan Peratruan Per-Undang-undangan c). Menghilangkan Ego Sektoral.

\section{B. Pembahasan}

Pembahasan omnibus law sebagai solusi hiperregulasi menuju sonkronisasi peraturan per-undang-undangan di Indonesia dapat dijelaskan melalui dua bahasan utama yaitu terkait dengan konsep omnibus law dan praktek diberbagai negara dan omnibus law sebagai solusi hiperregulasi menuju sonkronisasi dan harmonisasi peraturan perundang undangan di Indonesia

\section{Konsep Pembentukan Regulasi dan Omnibus Law}

Regulasi atau peraturan perundang-undangan mengandung dua makna : produk dan proses. Sebagai suatu produk, peraturan perundang-undangan bukanlah merupakan suatu konsep tunggal. Sebagaimana ditunjukkan pada namanya, ia merupakan pengertian kumpulan (Belanda : verzamelbegrip/ Inggris : collective term) yang didalamnya tercakup berbagai jenis peraturan perundang-undangan, mulai dari tingkat yang paling tinggi sampai yang paling rendah. Begitu pula sebagai proses, pembentukan berbagai jenis peraturan perundang-undangan tersebut memiliki proses tersendiri yang dalam beberapa hal berbeda, disamping mengandung pula persamaan, antara jenis peraturan yang satu dengan lainnya ${ }^{4}$.

Proses lahirnya suatu produk peraturan perundang-undangan setidaknya melewati

3 (tiga) koridor yang saling terkait; koridor administrasi, koridor akademik, dan koridor

\footnotetext{
${ }^{3}$ Wisnaeni, F. (2013). Implikasi Perubahan Uud 1945 Terhadap Cara Pengisisan Jabatan Presiden Dan/Atau Wakil Presiden Serta Pemberhentian Presiden Dan/Atau Wakil Presiden Dalam Masa Jabatannya. Masalah-Masalah Hukum, 42(2), 181-186. doi: http://dx.doi.org/10.14710/mmh.42.2.2013.181-186

${ }^{4}$ Lita Tyesta ALW, Aspek Penting Reformasi Regulasi (Perspektif Pembentukan Peraturan Perundangan), Orasi Ilmiah Disampaikan Pada Dies Natalis Ke-61 Fakultas Hukum Universitas Diponegoro, Semarang, 9 Januari 2018, Hal, 3
} 
politik (Yusril Ihza Mahendra, 2004). (1) Koridor administrasi mensyaratkan dipatuhinya segala ketentuan yang mengatur mengenai proses pembentukan peraturan perundangundangan; (2) koridor akademik menghendaki suatu rancangan peraturan harus dapat dipertanggungjawabkan secara akademik; (3) koridor politik tidak saja menyangkut kelembagaan politik tetapi secara substansi rancangan peraturan tersebut harus mampu menyerap dan sejalan dengan aspirasi publik. Oleh karena itu, lahirnya suatu peraturan perundang-undang merupakan hasil dari suatu proses yang tidak sederhana, bahkan dapat dikatakan kompleks karena banyak faktor dan actor terkait yang harus mendapat perhatian dalam proses tersebut.

Seperti telah saya sebutkan, bahwa suatu regulasi memang melibatkan banyak sekali faktor dan aktor dalam pembentukannya, sekurangnya terdapat 5 teori yang telah dirangkum Otto, Stoter dan Arnscheidt (J.M. Otto, W.S.R. Stoter \& J. Arnscheidt,2004), yang dapat digunakan untuk menggambarkan faktor-faktor yang berpengaruh dalam pembentukan peraturan perundangan terhadap kualitas dan isi (content) dari peraturan perundangan, yaitu : (1) synoptic policy-phases theory (teori tahapan kebijakan sinoptik), (2) the agenda-building theory (teori pembentukan agenda), ${ }^{5}$ (3) the elite ideology theory (teori ideologi elit), (4) the bureaupolitics theory or organizational politics theory (teori politik-biro atau teori politik-organisasi), dan (5) the four rationalities theory (teori empat dimensi rasionalitas).

Sebagai salah satu pilar penting dalam pembentukan peraturan perundangan, sebenarnya Undang-Undang No. 12 Tahun 2011 sudah mengalami banyak “penyempurnaan” dibanding Undang-Undang Nomor 10 Tahun 2004, diantaranya :

(1) penambahan ketetapan MPR masuk ke dalam salah satu hierarki peraturan perundang-undangan,

(2) cakupan perencanaan tidak hanya prolegnas dan prolegda saja namun juga mencakup peraturan perundang-undangan lainnya,

(3) pengaturan mekanisme pembahasan rancangan undang-undang,

(4) pengaturan naskah akademik sebagai persyaratan sebuah rancangan undang-undang,

\footnotetext{
${ }^{5}$ Krutz, Glen S. "Getting around Gridlock: The Effect of Omnibus Utilization on Legislative Productivity." Legislative Studies Quarterly, vol. 25, no. 4, 2000, pp. 533-549. JSTOR, www.jstor.org/stable/440433.
} 
(5) pengikutsertaan peneliti dan akademisi dalam penyusunan rancangan undangundang, serta.

(6) penambahan teknik penyusunan rancangan undang-undang dalam Lampiran 1.16

Meskipun demikian, Undang-Undang ini juga tak lepas dari masalah karena "kekurangan" yang terkandung didalamnya. Baru berumur satu tahun, Undang-Undang ini sudah kena semprit Mahkamah Konstitusi melalui putusan Nomor 92/PUU-X/2012. Melalui Putusan itu pula, MK dapat dikatakan telah "mengembalikan" kewenangan konstitusional Dewan Perwakilan Daerah (DPD) dalam legislasi sebagaimana digariskan Undang-Undang Dasar Negara Republik Indonesia Tahun 1945 (UUD 1945). ${ }^{6}$ Dalam Putusan itu, MK mengabulkan sebagian permohonan DPD selaku Pemohon untuk membatalkan beberapa ketentuan dalam UU yang dinilai mereduksi kewenangan DPD dalam proses legislasi. Putusan MK ini bukan sekedar soal "pengembalian" kewenangan konstitusional DPD semata tetapi lebih pada persoalan terjadinya sebuah inkonsistensi, yaitu "penghilangan mandat konstitusional" sebuah lembaga negara yang seharusnya memiliki kewenangan legislasi.

Tentang bagaimana implikasi dan implementasi Putusan MK adalah persoalan lain, tidak kalah penting justru adalah, bagaimana dengan "belantara ribuan" peraturan perundangan yang lainnya yang jumlahnya disajikan dalam grafik berikut ini, yaitu Regulasi Yang Terbit 2000 - 2015, sebagaimana diuraiakn oleh data sebagai berikut.

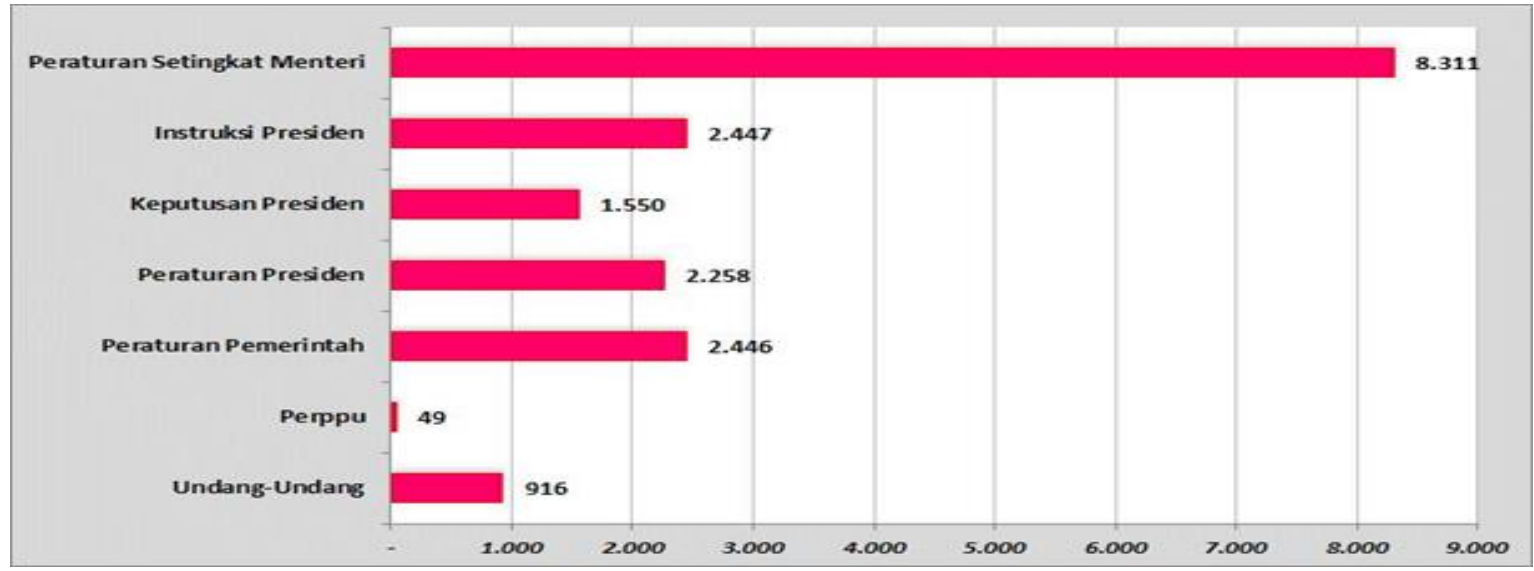

Gambar-1 : Regulasi Yang Terbit 2000 - 2015

(Sumber : Kementerian PPN/Bappenas, 2015).

${ }^{6}$ Diamantina, Amalia. UU NO 6 Tahun 2014 Tentang Desa Sebagai Manifestasi Penegakan Pasal 18 B AYAT (2) UUD NRI Tahun 1945. Masalah-Masalah Hukum, [S.1.], v. 45, n. 1, p. 33-40, jan. 2016. ISSN 2527-4716.

Available at: . Date accessed: 08 dec. 2019. doi: http://dx.doi.org/10.14710/mmh.45.1.2016.33-40 
Regulasi tersebut diatas dapat dibagi lagi ke dalam pelbagai kategori dan tersebar dalam bentuk peraturan di tingkat pusat dan daerah dengan sebaran sebagai berikut.

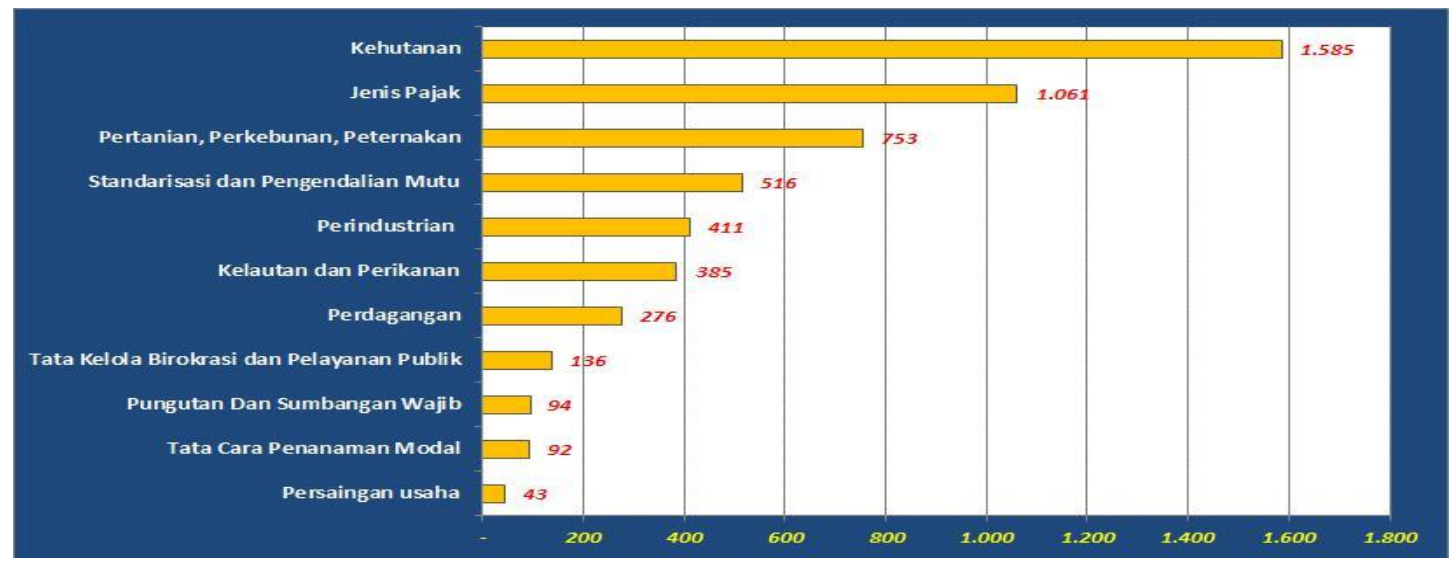

Gambar-2 : Sebaran Regulasi

(Sumber : Kementerian PPN/Bappenas, 2015)

Berbagai peraturan perundangan yang datanya disajikan nyatanya juga tidak sepi dari berbagai masalah. Hal ini dapat kita lihat dari jumlah pengajuan judicial review undangundang yang diajukan ke MK seperti disajikan dalam data berikut.

\section{Omnibus Law Sebagai Solusi Hiperregulasi Menuju Sonkronisasi dan Harmonisasi Peraturan Perundang Undangan.}

Kehadiran Omnibus sebagai dapat menjadi solusi dari adanya hiperregulasi menuju sonkronisasi dan harmonisasi peraturan perundang undangan di Indonesia. Omnibus Law sendiri berasal dari bahasa Latin yang artinya "for everything". Black Law Dictionary yang menjadi rujukan definisi istilah hukum di Barat juga sudah menjelaskan apa itu omnibus law. ${ }^{7}$ Satu regulasi baru dibentuk sekaligus menggantikan lebih dari satu regulasi lain yang sudah berlaku. Konsep ini bisa saja hanya menggantikan beberapa pasal di satu regulasi dan saat bersamaan mencabut seluruh isi regulasi lain. Omnibu Law hanya sebagai metode dalam menyusun suatu undang-undang. Implementasi konsep omnibus law dalam peraturan perundang-undangan ini lebih mengarah pada tradisi Anglo-Saxon Common Law. Irlandia, tahun 2008, Irlandia telah menerbitkan Undang Undang yang menggunakan metode Omnibus Law yang mencabut kurang lebih 3.225 undang-undang.

\footnotetext{
${ }^{7}$ Benjamin L. Liebman, Recent Legislation: Constitutional Law - Congress Imposes New Restrictions on Use of Funds by the Legal Services Corporation - Omnibus Consolidated Rescissions and Appropriations Act of 1996, Pub. L. No. 104-134, 110 Stat. 1321, 110 Harv. L. Rev. 1346 (1997). Available at: https://scholarship.law.columbia.edu/faculty_scholarship/406
} 
Pun begitu lanya dengan yang terjadi dinegara negara lain seperti Inggris, Australia, Jerman, Turki, Filipina, Kamboja, Vietnam, Malaysia, dan Singapura.

Keunggulan metode omnibus law adalah kepraktisan mengoreksi banyak regulasi bermasalah. $^{8}$ Meningkatkan kecepatan dalam penyusunan undang-undang, dengan menyusun sebuah omnibus law sekaligus mengoreksi undang-undang bermasalah yang sedang berlaku. Pendekatan omnibus law juga bisa menjadi solusi atas tumpang tindih regulasi di Indonesia baik dalam hubungan hierarki sejajar horizontal maupun vertikal. Dalam prakteknya penyusunan omnibus law berbiaya mahal dan tidak sederhana karena substansinya pasti multisektor dan dipersiapkan untuk super power. Namun nyatanya dengan metode Omnibus law dapat mengatasi konflik peraturan perundang-undangan secara cepat, efektif, dan efisien.

\section{Simpulan}

Berdasakran Keseluruhan Uraian tersbeut maka penerapan konsep omnibus law sebagai solusi hiperregulasi regulasi di Indonesia dapat segera direalisasikan. Hiperegulasi di Indonesia terjadi pada setiap tingkatan peraturan perundang undangan. Potensi tumpang tindih peraturan perundang undagan diantarannya terdapat 7621 peraturan menteri, 765 peraturan presiden, 452 peraturan pemerintah dan sekitar 30.000 peratruan daerah. Hiperregulasi tersebut memberikan beban dalam melakukan sonkronisasi dan harmonisasi peraturan perundang undangan di Indonesia. Bahkan tidak ada satupun lembaga yang dapat melakukan monitoring dan evaluasi terhadap adanya hiperegulasi tersebut. Sonkronisasi dan Harmonisasi dilakukan dalam kerangka empat pilar sebagai dasar negara Rebublik Indonesia. Dengan demikian, perlu dilakukan diterapkannya kajian penerapan metode omnibus law sebagai solusi atas hiperregulasi perundang undangan di Indonesia.

\section{Daftar Pustaka}

Busroh, Firman Freaddy. Konseptualisasi Omnibus Law Dalam Menyelesaikan Permasalahan Regulasi Pertanahan. Arena Hukum, [S.1.], v. 10, n. 2, p. 227-250, aug. 2017. ISSN 2527-4406. Available at: . Date accessed: 08 dec. 2019. doi: http://dx.doi.org/10.21776/ub.arenahukum.2017.01002.4

\footnotetext{
${ }^{8}$ Krutz, Glen S. "Getting around Gridlock: The Effect of Omnibus Utilization on Legislative Productivity.” Legislative Studies Quarterly, vol. 25, no. 4, 2000, pp. 533-549. JSTOR, www.jstor.org/stable/440433.
} 
Krutz, Glen S. "Getting around Gridlock: The Effect of Omnibus Utilization on Legislative Productivity." Legislative Studies Quarterly, vol. 25, no. 4, 2000, pp. 533-549. JSTOR, www.jstor.org/stable/440433.

Wisnaeni, F. (2013). Implikasi Perubahan Uud 1945 Terhadap Cara Pengisisan Jabatan Presiden Dan/Atau Wakil Presiden Serta Pemberhentian Presiden Dan/Atau Wakil Presiden Dalam Masa Jabatannya. Masalah-Masalah Hukum, 42(2), 181-186. doi: http://dx.doi.org/10.14710/mmh.42.2.2013.181-186

Lita Tyesta ALW, Aspek Penting Reformasi Regulasi (Perspektif Pembentukan Peraturan Perundangan), Orasi Ilmiah Disampaikan Pada Dies Natalis Ke-61 Fakultas Hukum Universitas Diponegoro, Semarang, 9 Januari 2018, Hal, 3.

Diamantina, Amalia. UU NO 6 Tahun 2014 Tentang Desa Sebagai Manifestasi Penegakan Pasal 18 B AYAT (2) UUD NRI Tahun 1945. Masalah-Masalah Hukum, [S.l.], v. 45, n. 1, p. 33-40, jan. 2016. ISSN 2527-4716. Available at: . Date accessed: 08 dec. 2019. doi: http://dx.doi.org/10.14710/mmh.45.1.2016.33-40

Dyah Wijaningsih, Islamiyati Muhyidin, Ro'fah Setyowati. Access To Justice Nasabah Perbankan Syariah Pasca Putusan Mahkamah Konstitusi Nomor 93/PUU-X/2012. MasalahMasalah Hukum, [S.1.], v. 43, n. 3, p. 411-419, july 2014. ISSN 2527-4716. Available at: . Date accessed: 08 dec. 2019. doi: http://dx.doi.org/10.14710/mmh.43.3.2014.411-419

P Pedoman Analisis dan Evaluasi Hukum BPHN Tahun 2019.

Pedoman Pengujian Kebijakan Konstitusional, Untuk Pemenuhan Hak Konsitusional Dan Penghapusan Diskriminasi Terhadap Perempuan, Komnas Perempuan, Jakarta, 2016, hal 8.

Esmi Warassih, Pranata Hukum, Sebuah Telaah Sosiologis, Pustaka Magister, 2016

Han, Sam and Ganow, Scot, Model Omnibus Privacy Statute (September 9, 2010). University of Dayton Law Review, Vol. 35, No. 3, p. 303, 2010. Available at SSRN: https://ssrn.com/abstract=1922189

Benjamin L. Liebman, Recent Legislation: Constitutional Law - Congress Imposes New Restrictions on Use of Funds by the Legal Services Corporation - Omnibus Consolidated Rescissions and Appropriations Act of 1996, Pub. L. No. 104-134, 110 Stat. 1321, 110 Harv. L. Rev. 1346 (1997). Available at: https://scholarship.law.columbia.edu/faculty_scholarship/406 